\title{
Synthesis of Enaminones by a Palladium-Catalyzed Four-Component Carbonylative Addition Reaction
}

\author{
Liangguang Wang*a \\ Juan $\mathrm{Ma}^{\mathrm{a}}$ \\ Xia Chen ${ }^{b}$ \\ Xiaoyu Zhou*b \\ ${ }^{a}$ College of Chemistry and Chemical Engineering, \\ Anshun University, Anshun, 561000, P. R. of China \\ wang825663@163.com \\ b Department of Chemistry and Chemical Engineering, \\ Liupanshui Normal University, Liupanshui, 553004, \\ P. R. of China \\ zhouxiaoyu20062006@126.com
}
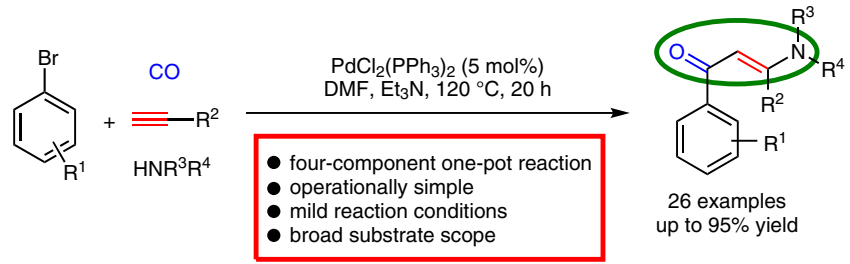

26 examples up to $95 \%$ yield
Received: 05.06.2017

Accepted after revision: 03.07.2017

Published online: 08.08 .2017

DOI: 10.1055/s-0036-1590976; Art ID: st-2017-w0436-

Abstract A palladium-catalyzed carbonylative addition reaction of aryl bromides, amines, and alkynes has been developed. The reaction occurs readily in $\mathrm{N}, \mathrm{N}$-dimethylformamide with $\mathrm{PdCl}_{2}\left(\mathrm{PPh}_{3}\right)_{2}$ as a catalyst to give the corresponding enaminones in medium to excellent yields. Furthermore, a mechanism for the palladium-catalyzed four-component carbonylative addition reaction is proposed.

Key words palladium catalysis, multicomponent reaction, carbonylative addition, enaminones, aryl bromides, amines

For economic and environmental reasons, environmentally friendly chemistry has attracted considerable attention in modern organic synthesis. ${ }^{1}$ Multicomponent reactions (MCRs) ${ }^{2}$ can produce target products directly by simple operations with high efficiency and with reduced waste generation compared with conventional methods in organic synthesis. ${ }^{3}$ Palladium-catalyzed carbonylation is a representative $\mathrm{MCR}^{4}$ that has played an important role in the synthesis of carbonyl compounds because of its high selectivity and mild reaction conditions. In recent years, palladium-catalyzed three-component carbonylative coupling reactions of aryl halides with organometallic reagents, alkenes, alkynes, amines, alcohols, water, or hydrogen have been studied. ${ }^{5}$ However, much to our regret, there have been few reports on palladium-catalyzed four-component carbonylations. ${ }^{6}$

Recently, Wu and co-workers reported a palladium-catalyzed four-component carbonylation for the synthesis of $4(3 \mathrm{H})$-quinazolinones or thiochromenones. ${ }^{7}$ In 2014, Bao and co-workers reported the palladium-catalyzed threecomponent carbonylative addition reaction using 1,4bis(diphenylphosphino)butane (DPPB) as a ligand in DMF. ${ }^{8}$ In the present study, we found that the reductive elimina- tion of the acylpalladium amine intermediate was interrupted by coordination of an alkyne and that a carbonylative addition reaction of an aryl bromide, $\mathrm{CO}$, an amine, and an alkyne successfully occurred with $\mathrm{PdCl}_{2}\left(\mathrm{PPh}_{3}\right)_{2}$ as catalyst at $120^{\circ} \mathrm{C}$ in DMF (Scheme 1 ), thereby providing an efficient and novel strategy for the synthesis of enaminones. ${ }^{9}$ The method has several prominent advantages over conventional methods, such as mild reaction conditions, high efficiency, simple starting materials, and straightforward operations.

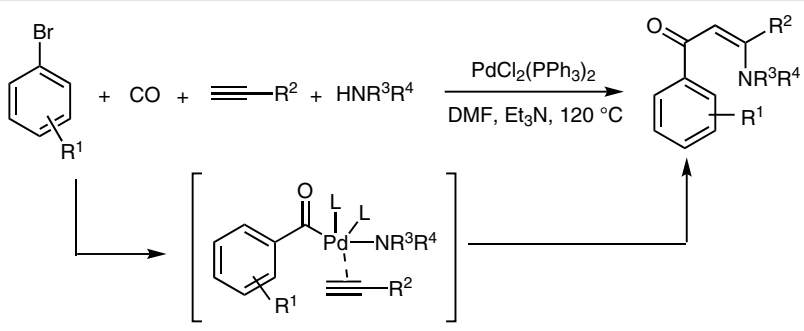

Scheme 1 Palladium-catalyzed four-component one-pot synthesis of enaminones

Initially, we began our study by using 1-(4-bromophenyl)ethanone (1a, $0.5 \mathrm{mmol}$ ), ethynylbenzene (2a, 0.6 mmol), $\mathrm{HNEt}_{2}$ (3a, $0.75 \mathrm{mmol}$ ), and CO (5 atm) as substrates and $\mathrm{PdCl}_{2}$ (5 mol\%) as a catalyst to optimize the reaction conditions. The expected reaction occurred, and 1-(4acetylphenyl)-3-(diethylamino)-3-phenylprop-2-en-1-one (4a) was obtained in 20,22, and $45 \%$ yields in the presence of the bidentate ligands DPPB, 1,3-bis(diphenylphosphino)propane (DPPP), and 1,2-bis(diphenylphosphino)ethane (DPPE) respectively (Table 1 , entries $1-3$ ). To our delight, however, the isolated yield of product $\mathbf{4 a}$ improved to $86 \%$ when $\mathrm{PPh}_{3}$ was used as the ligand in DMF solvent (entry 4). A decreased yield of $\mathbf{4 a}$ was obtained when the reaction medium DMF was replaced by DMSO, MeCN or 1,4-dioxane 
(entries 5-7). Note that no product 4a was produced when the reaction was performed in toluene (entry 8 ). The yield of $4 \mathbf{a}$ did not improved significantly when the reaction temperature was increased to $130{ }^{\circ} \mathrm{C}$ (entry 9; yield $87 \%$ ), and the yield of $\mathbf{4 a}$ decreased to $65 \%$ when the reaction temperature was reduced to $110{ }^{\circ} \mathrm{C}$ (entry 10). The optimal reaction temperature is therefore $120^{\circ} \mathrm{C}$. The yield of $4 \mathbf{a}$ decreased when $\mathrm{K}_{2} \mathrm{CO}_{3}, \mathrm{~K}_{3} \mathrm{PO}_{4}, \mathrm{Bu}_{3} \mathrm{~N}$, or DIPEA was used as an additive (entries 11-14; yield 28-68\%). Furthermore, the reaction did not proceed in the absence of an additive (entry 15). Interestingly, the four-component reaction proceed smoothly with $\mathrm{PdCl}_{2}\left(\mathrm{PPh}_{3}\right)_{2}$ as the catalyst to give product $4 \mathbf{a}$ in $86 \%$ yield (entry 16 ).

Table 1 Reaction Condition Screening ${ }^{\mathrm{a}}$

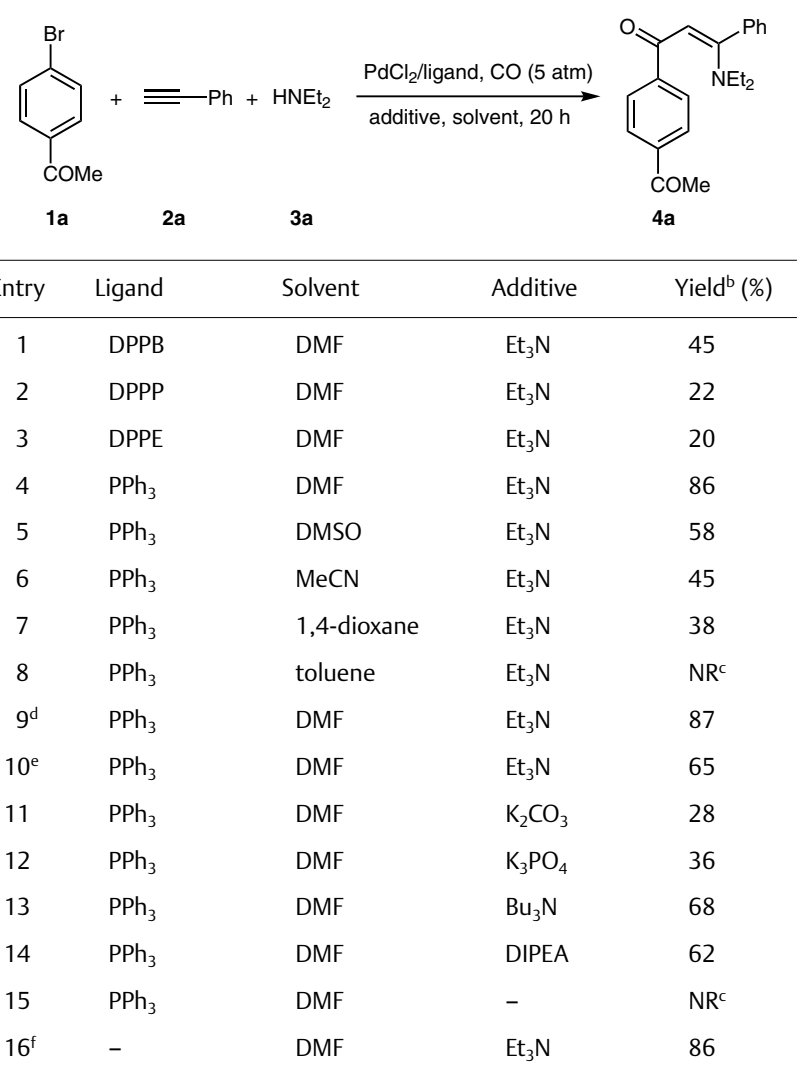

a Reaction conditions: 1a (0.5 mmol), 2a $(0.6 \mathrm{mmol}), 3 a(0.75 \mathrm{mmol}), \mathrm{CO}$ (5 atm), $\mathrm{PdCl}_{2}(5 \mathrm{~mol} \%)$, ligand (10 mol\%), additive (1.5 mmol), solvent (4 $\mathrm{mL}), 120^{\circ} \mathrm{C}, 20 \mathrm{~h}$.

b Isolated yield.

c No reaction; the starting materials were recovered.

d At $130^{\circ} \mathrm{C}$.

e At $110^{\circ} \mathrm{C}$.

${ }^{\mathrm{f}} \mathrm{PdCl}_{2}\left(\mathrm{PPh}_{3}\right)_{2}$ (5 mol\%) was used instead of $\mathrm{PdCl}_{2}$.

From the optimization of the catalytic system, solvent, temperature, and additive, the optimal conditions for the palladium-catalyzed four-component carbonylative addition reaction were identified as follows: $\mathrm{PdCl}_{2}\left(\mathrm{PPh}_{3}\right)_{2}$ (5 mol\%) as catalyst, $\mathrm{Et}_{3} \mathrm{~N}$ (3.0 equiv) as additive, and DMF (4 $\mathrm{mL})$ as solvent in the presence of $\mathrm{CO}(5 \mathrm{~atm})$ at $120{ }^{\circ} \mathrm{C}$ for 20 h. Next, we tested the reactivity of various alkynes, aryl bromides, and amines under these optimized reaction conditions.

We first investigated the reactions of various aryl bromides with ethynylbenzene (2a), $\mathrm{HNEt}_{2}$ (3a), and CO under the optimized conditions (Scheme 2).1-(4-Bromophenyl)ethanone (1a) and 1-(3-bromophenyl)ethanone (1b) gave good yields of products $\mathbf{4 a}(86 \%)$ and $\mathbf{4 b}$ (78\%), respectively. However, when 1-(2-bromophenyl)ethanone (1c) was used as a substrate, the reaction did not occur. Aryl bromides with an electron-withdrawing group in the paraposition 1d-h reacted smoothly to give the corresponding products $\mathbf{4 d - h}$ in moderate to good yields (71-86\%). On the other hand, products $\mathbf{4 i}(58 \%)$ and $\mathbf{4 j}$ (45\%) were produced in lower yields from bromobenzene (1i) and 1-bromonaphthalene $(\mathbf{1 j})$, respectively.

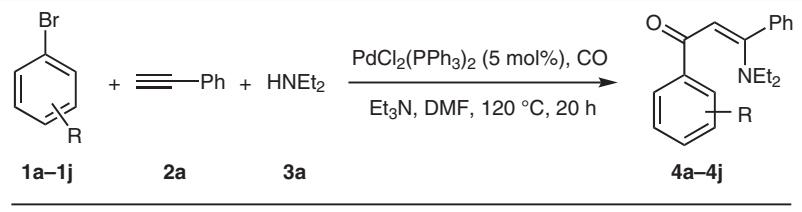

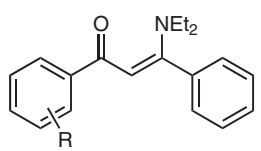

4a, $\mathrm{R}=4-\mathrm{COMe}, 86 \%$ 4b, $R=3-\mathrm{COMe}, 78 \%$ 4c, $\mathrm{R}=2-\mathrm{COMe}, 0 \%{ }^{\mathrm{a}}$

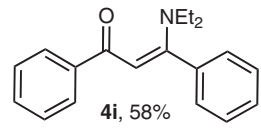

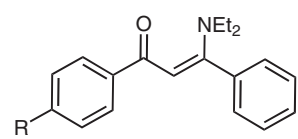

4d, $\mathrm{R}=\mathrm{CHO}, 72 \% ; \mathbf{4 e}, \mathrm{R}=\mathrm{F}, 71 \%$ 4f, $\mathrm{R}=\mathrm{CF}_{3}, 86 \% ; \mathbf{4 g}, \mathrm{R}=\mathrm{CN}, 84 \%$ $4 \mathrm{~h}, \mathrm{R}=\mathrm{COOMe}, 83 \%$

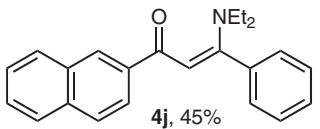

Scheme 2 Palladium-catalyzed carbonylative addition reactions of various aryl bromides. Reagents and conditions: $\mathbf{1 a}-\mathbf{j}(0.5 \mathrm{mmol}), \mathbf{2 a}$ (0.6mmol), $3 \mathrm{a}$ (0.75 mmol), $\mathrm{CO}(5 \mathrm{~atm}), \mathrm{PdCl}_{2}\left(\mathrm{PPh}_{3}\right)(5 \mathrm{~mol} \%), \mathrm{Et}_{3} \mathrm{~N}(1.5$ $\mathrm{mmol}), \mathrm{DMF}(4 \mathrm{~mL}), 120^{\circ} \mathrm{C}, 20 \mathrm{~h}$. Isolated yields are reported. ${ }^{\mathrm{a}}$ The starting materials were recovered.

We then studied the reactivity of various alkynes under the optimal conditions (Scheme 3 ). When the aromatic alkynes $\mathbf{2 b}(\mathrm{R}=4$-Tol $)$ and $\mathbf{2 c}(\mathrm{R}=3$-Tol $)$ were subjected in the reaction, the corresponding products $\mathbf{4 k}$ and $\mathbf{4 1}$ were obtained in excellent yields of 93 and 92\%, respectively, whereas $2 d$ ( $R=2$-Tol) gave only a moderate yield of $\mathbf{4 m}$ (78\%). Enaminones 4n-p were produced in excellent yields of 95,92 , and $94 \%$, respectively, from aromatic alkynes containing electron-donating groups in the para-position; however, lower yields were obtained when the aromatic alkynes contained electron-withdrawing groups in the para-position (4q; 56\%: 4r; 53\%). Interestingly, for aromatic alkyne $\mathbf{2 j}$ with a vinyl group in the para-position, product 4s (85\%) was obtained, showing that the palladiumcatalyzed carbonylative addition is highly selective towards the $\mathrm{C} \equiv \mathrm{C}$ triple bond. More importantly, aliphatic alkynes ethynylcyclohexane (2k) and oct-1-yne (21) and the hetero- 


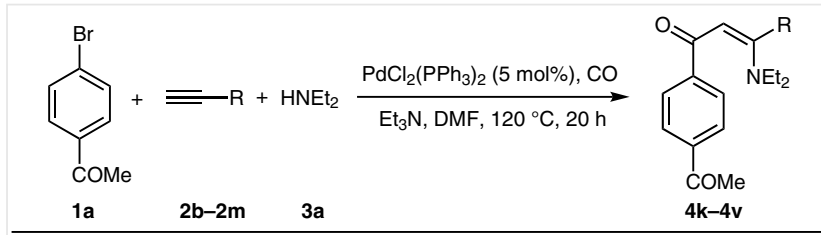<smiles>CCN(CC)/C(=C/C(=O)c1ccc(OC)cc1)c1ccc([N+](=O)[O-])cc1</smiles><smiles>CCN(CC)/C(=C/C(=O)c1ccc(C(C)=O)cc1)c1cccc([N+](=O)[O-])c1</smiles><smiles>CCN(CC)/C(=C\C(=O)c1ccc(C(C)=O)cc1)c1ccccc1C</smiles><smiles>CCN(CC)/C(=C/C(=O)c1ccc(OC)cc1)c1ccc(Br)cc1</smiles><smiles>CCN/C(=C\C(=O)c1ccc(OC)cc1)c1ccc(OC)cc1</smiles><smiles>CCNC(=CC(=O)c1ccc(C(C)(C)C)cc1)c1ccc(F)cc1</smiles><smiles>CCNC(=CC(=O)c1ccc(OC)cc1)c1ccc(C=O)cc1</smiles><smiles>C=Cc1ccc(/C(=C/C(=O)c2ccc(C(C)=O)cc2)NCC)cc1</smiles><smiles>CCN(CC)/C(=C/C(=O)c1ccc(OC)cc1)C1CCCCC1</smiles><smiles>CCCCCCC(=CC(=O)c1ccc(OC)cc1)N(CC)CC</smiles><smiles>CCN(CC)/C(=C/C(=O)c1ccc(C(C)=O)cc1)c1cccnc1</smiles>

Scheme 3 Palladium-catalyzed carbonylative addition reaction of various terminal alkynes. Reagents and conditions: $\mathbf{2 a}(0.5 \mathrm{mmol}), \mathbf{2 b}-\mathbf{m}$ (0.6mmol), 3a (0.75 mmol), $\mathrm{CO}(5 \mathrm{~atm}), \mathrm{PdCl}_{2}\left(\mathrm{PPh}_{3}\right)_{2}(5 \mathrm{~mol} \%), \mathrm{Et}_{3} \mathrm{~N}$ (1.5 mmol), DMF $(4 \mathrm{~mL}), 120^{\circ} \mathrm{C}, 20 \mathrm{~h}$. Isolated yields are reported.

cyclic alkyne 3-ethynylpyridine ( $\mathbf{2 m}$ ) also reacted under the optimal conditions to give products $4 \mathbf{t}(84 \%), \mathbf{4 u}(82 \%)$, and 4v (91\%), respectively, in high yields.

Next, we used several secondary and primary amines in the palladium-catalyzed carbonylative addition reaction
(Scheme 4). The secondary amines dimethylamine (3b) and dibutylamine (3c) gave products $4 \mathbf{w}(87 \%)$ and $4 \mathbf{x}(91 \%)$, respectively, in high yields. Primary amine butylamine (3d) gave a lower yield of product $4 \mathbf{y}$ (46\%). However, the reaction did not occur smoothly when aniline (3e) was used.

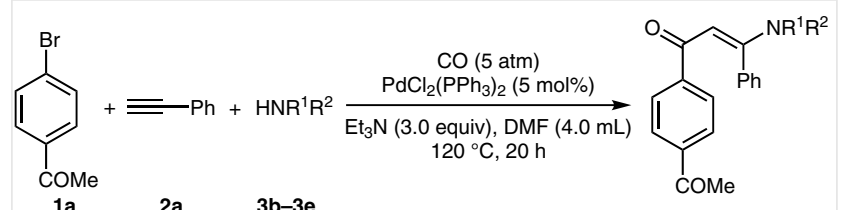

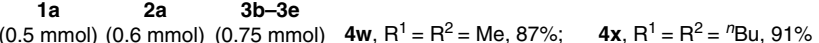
$4 y, R^{1}=H, R^{2}={ }^{n} B u, 46 \% ; 4 z, R^{1}=H, R^{2}=P h, 0 \%$

Scheme 4 Palladium-catalyzed carbonylative addition reactions of various amines

To explore the mechanism of this reaction, we performed several control experiments (Scheme 5). The reaction of bromide $\mathbf{1 a}$, ethynylbenzene (2a), and $\mathrm{CO}$ did not occur in DMF at $120^{\circ} \mathrm{C}$ for $20 \mathrm{~h}$ (Scheme 1, eq 1), whereas the reaction of bromide 1a, diethylamine (3a), and CO did occur under these conditions to give the corresponding product $\mathbf{5 a}$ in $92 \%$ yield (Scheme 1, eq 2). These results show that, in the four-component carbonylative reaction system, the reaction occurs initially between the aryl bromide, the amine, and $\mathrm{CO}$, rather than the aryl bromide, the alkyne, and $\mathrm{CO}$.

Finally, a plausible reaction mechanism (Scheme 6) is proposed based on the control experiments and the reported mechanism of palladium-catalyzed carbonylation. ${ }^{10}$ Bromide 1a undergoes oxidative addition with $\operatorname{Pd}(0)$ to form the arylpalladium intermediate $\mathbf{A}$. Subsequently, this undergoes $\mathrm{CO}$ insertion to produce an acylpalladium intermediate $\mathbf{B}$, which react with nucleophile $\mathbf{3 a}$ to produce intermediate $\mathbf{C}$ in the presence of $\mathrm{Et}_{3} \mathrm{~N}$. The reductive elimination of intermediate $\mathbf{C}$ is interrupted by the coordination of $\mathbf{2 a}$ to give the $\pi$-alkyne(acyl)palladium intermediate $\mathbf{D} .^{11}$ Insertion then occurs to form intermediate $\mathbf{E}$, which gives a $\operatorname{Pd}(0)$ species and product $4 a$ through reductive elimination.

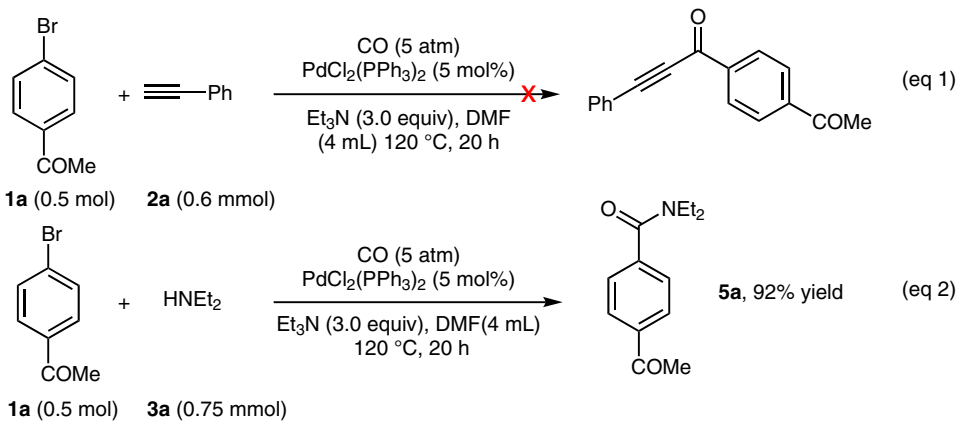

Scheme 5 Control experiments 


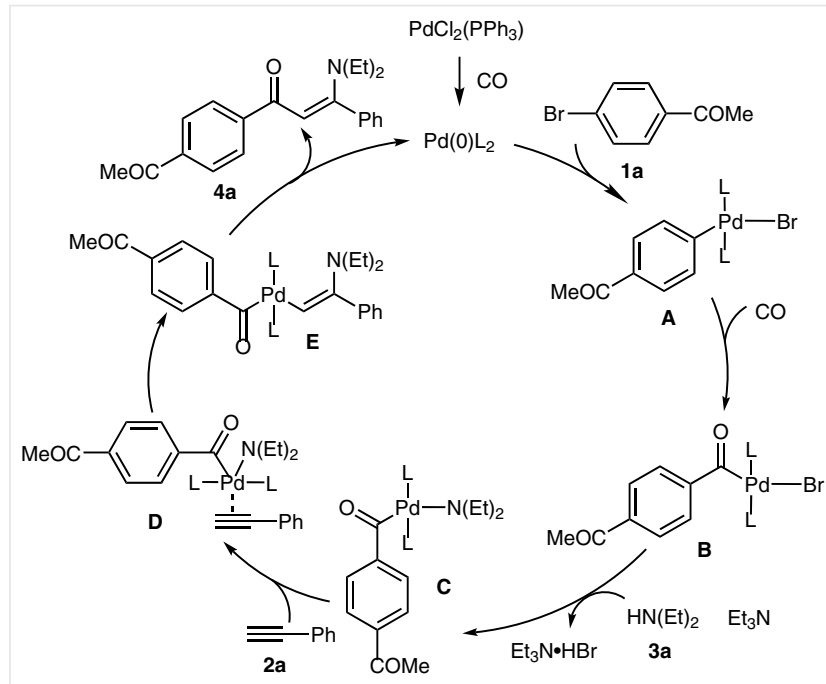

Scheme 6 Proposed reaction mechanism

In summary, we have developed a new type of palladiumcatalyzed one-pot carbonylative addition reaction of aryl bromides, alkynes, and amines. The reductive elimination of an acylpalladium amine intermediate is interrupted by the coordination of an alkyne, and a carbonylative addition reaction occurs smoothly to produce enaminones in moderate to excellent yields. ${ }^{12}$ Fortunately, the present method has distinct advantages, such as compatibility with many functional groups, high selectivity, simplicity of the catalytic system and substrates, and mild reaction conditions. The principle of the reaction will provide a new strategy for developing new types of catalytic carbonylative addition reactions of alkenes.

\section{Funding Information}

This work was supported by the Foundation of Science and Technology Department of Guizhou Province (qiankeheJzi [2015] number 2003) and the Doctoral Foundation of Anshun University (asubsjj201501).

\section{Supporting Information}

Supporting information for this article is available online at https://doi.org/10.1055/s-0036-1590976.

\section{References and Notes}

(1) van der Heijden, G.; Ruijter, E.; Orru, R. V. A. Synlett 2013, 24, 666.

(2) (a) Rotstein, B. H.; Zaretsky, S.; Rai, V.; Yudin, A. K. Chem. Rev. 2014, 114, 8323. (b) Estévez, V.; Villacampa, M.; Menéndez, J. C. Chem. Soc. Rev. 2014, 43, 4633. (c) Slobbe, P.; Ruijter, E.; Orru, R. V. A. Med. Chem. Commun. 2012, 3, 1189. (d) Touré, B. B.; Hall, D. G. Chem. Rev. 2009, 109, 4439.
(3) For selected reviews, see: (a) Cioc, R. C.; Ruijter, E.; Orru, R. V. A. Green Chem. 2014, 16, 2958. (b) Guo, X.; Hu, W. Acc. Chem. Res. 2013, 46, 2427. (c) Gu, Y. Green Chem. 2012, 14, 2091. (d) Estévez, V.; Villacampa, M.; Menéndez, J. C. Chem. Soc. Rev. 2010, 39, 4402. (e) D'Souza, D. M.; Müller, T. J. J. Chem. Soc. Rev. 2007, 36, 1095. (f) Dömling, A. Chem. Rev. 2006, 106, 17.

(4) (a) Shen, C.; Wu, X.-F. Chem. Eur. J. 2017, 23, 2973. (b) Peng, J.-B.; Qi, X.; Wu, X.-F. Synlett 2017, 28, 175.

(5) For selected reviews, see: (a) Dong, K.; Wu, X.-F. Angew. Chem. Int. Ed. 2017, 56, 5399. (b) Wu, X.-F. RSC Adv. 2016, 6, 83831. (c) Wu, X.-F.; Neumann, H.; Beller, M. Chem. Rev. 2013, 113, 1. (d) Wu, X.-F.; Neumann, H.; Beller, M. Chem. Soc. Rev. 2011, 40, 4986. (e) Liu, Q.; Zhang, H.; Lei, A. Angew. Chem. Int. Ed. 2011, 50, 10788. (f) Brennführer, A.; Neumann, H.; Beller, M. Angew. Chem. Int. Ed. 2009, 48, 4114. (g) Barnard, C. F. J. Organometallics 2008, 27, 5402. (h) Modern Carbonylation Methods; Kollár, L., Ed.; Wiley-VCH: Weinheim, 2008.

(6) For selected papers, see: (a) Shen, C.; Spannenberg, A.; Auer, M.; Wu, X.-F. Adv. Synth. Catal. 2017, 359, 941. (b) Torres, G. M.; Quesnel, J. S.; Bijou, D.; Arndtsen, B. A. J. Am. Chem. Soc. 2016, 138, 7315. (c) Zhao, J.; Li, Z.; Song, S.; Wang, M.-A.; Fu, B.; Zhang, Z. Angew. Chem. Int. Ed. 2016, 55, 5545. (d) Wang, Q.; He, Y.-T.; Zhao, J.-H.; Qiu, Y.-F.; Zheng, L.; Hu, J.-Y.; Yang, Y.-C.; Liu, X.-Y.; Liang, Y.-M. Org. Lett. 2016, 18, 2664. (e) Liu, J.; Han, Z.; Wang, X.; Wang, Z.; Ding, K. J. Am. Chem. Soc. 2015, 137, 15346. (f) Cheng, J.; Qi, X.; Li, M.; Chen, P.; Liu, G. J. Am. Chem. Soc. 2015, 137, 2480. (g) Sumino, S.; Ui, T.; Ryu, I. Org. Lett. 2013, 15, 3142. (h) Fusano, A.; Sumino, S.; Fukuyama, T.; Ryu, I. Org. Lett. 2011, $13,2114$.

(7) (a) Shen, C.; Spannenberg, A.; Wu, X.-F. Angew. Chem. Int. Ed. 2016, 55, 5067. (b) He, L.; Li, H.; Neumann, H.; Beller, M.; Wu, X.-F. Angew. Chem. Int. Ed. 2014, 53, 1420.

(8) Zhang, S.; Wang, L.; Feng, X.; Bao, M. Org. Biomol. Chem. 2014, $12,7233$.

(9) For selected papers and reviews, see: (a) Zhu, Z.; Tang, X.; Li, J.; Li, X.; Wu, W.; Deng, G.; Jiang, H. Chem. Commun. 2017, 53, 3228. (b) Yang, Z.; Jiang, B.; Hao, W.-J.; Zhou, P.; Tu, S.-J.; Li, G. Chem. Commun. 2015, 51, 1267. (c) Shi, L.; Xue, L.; Lang, R.; Xia, C.; Li, F. ChemCatChem 2014, 6, 2560. (d) Yu, X.; Wang, L.; Feng, X.; Bao, M.; Yamamoto, Y. Chem. Commun. 2013, 49, 2885. (e) Cheng, G.; Zeng, X.; Shen, J.; Wang, X.; Cui, X. Angew. Chem. Int. Ed. 2013, 52, 13265. (f) Zhao, Y.; Deng, D.-S.; Ma, L.-F.; Ji, B.M.; Wang, L.-Y. Chem. Commun. 2013, 49, 10299. (g) Wu, X.-F.; Sundararaju, B.; Neumann, H.; Dixneuf, P. H.; Beller, M. Chem. Eur. J. 2011, 17, 106. (h) Cacchi, S.; Fabrizi, G.; Filisti, E. Org. Lett. 2008, 10, 2629. (i) Elassar, A.-Z. A.; El-Khair, A. A. Tetrahedron 2003, 59, 8463.

(10) Wu, X.-F.; Neumann, H.; Beller, M. Chem. Eur. J. 2010, 16, 9750.

(11) Cacchi, S.; Fabrizi, G. Chem. Rev. 2005, 105, 2873.

(12) Enaminones 4a-z; General Procedure

A mixture of the appropriate aryl bromide $\mathbf{1}(0.5 \mathrm{mmol})$, alkyne $2(0.6 \mathrm{mmol})$, amine $3(0.75 \mathrm{mmol}), \mathrm{PdCl}_{2}\left(\mathrm{PPh}_{3}\right)_{2}(17.5 \mathrm{mg}, 5$ mol\%), $\mathrm{Et}_{3} \mathrm{~N}(209 \mu \mathrm{L}, 1.5 \mathrm{mmol})$, and $\mathrm{DMF}(4.0 \mathrm{~mL})$ was placed in a $25 \mathrm{~mL}$ autoclave under $\mathrm{N}_{2}$. The autoclave was filled with $\mathrm{CO}$ to $5 \mathrm{~atm}$ pressure, and heated to $120^{\circ} \mathrm{C}$ for $20 \mathrm{~h}$. The product was extracted with EtOAc $(3 \times 5 \mathrm{~mL})$, and the organic layers were combined, washed with brine $(2 \times 5 \mathrm{~mL})$, dried $\left(\mathrm{Na}_{2} \mathrm{SO}_{4}\right)$, and concentrated under reduced pressure. The residue was then purified by chromatography (silica gel).

1-(4-Acetylphenyl)-3-(diethylamino)-3-phenylprop-2-en-1one (4a)

Pale-yellow solid; yield: $138.2 \mathrm{mg}(86 \%)$; $\mathrm{mp} 96-98^{\circ} \mathrm{C}$. IR (neat): 3474, 3059, 2976, 1683, 1625, 1479, 1461, 1439, 1357, 
$1265,1213,775 \mathrm{~cm}^{-1} .{ }^{1} \mathrm{H}$ NMR $\left(400 \mathrm{MHz}, \mathrm{CDCl}_{3}\right): \delta=7.92(\mathrm{~d}, J=$ $8.0 \mathrm{~Hz}, 2 \mathrm{H}), 7.87$ (d, J = 8.0 Hz, $2 \mathrm{H}), 7.45-7.23(\mathrm{~m}, 5 \mathrm{H}), 5.93$ (s, $1 \mathrm{H}), 3.51-2.90(\mathrm{~m}, 4 \mathrm{H}), 2.59$ (s, $3 \mathrm{H}), 1.47-0.94(\mathrm{~m}, 6 \mathrm{H}) .{ }^{13} \mathrm{C}$ NMR $\left(100 \mathrm{MHz}, \mathrm{CDCl}_{3}\right): \delta=198.0,185.9,164.1,146.2,138.2$,
137.0, 128.7, 128.5, 128.1, 127.8, 127.7, 93.1, 44.8, 26.9, 14.4. HRMS (EI): $\mathrm{m} / z\left[\mathrm{M}^{+}\right]$calcd for $\mathrm{C}_{21} \mathrm{H}_{23} \mathrm{NO}_{2}$ : 321.1729; found: 321.1735 . 